\title{
SENGKALAN, MAKNA PENANDA DALAM BENTUK KALIMAT ATAU GAMBAR INDAH SEBAGAI BAHASA KOMUNIKASI SENI
}

\author{
Febrian Wisnu Adi *)
}

\begin{abstract}
sengkalan is expression presentation of from public expression jawa, sengkalan lamba has three element that is between sentence or word, figure, and year. sengkalan casquette is a marker visualizinged in the form of picture, patrimony, statue, ornament, train representing from an expression forwarding of certain intention. presentation of sengkalan in wording based on meaning and karakteristikyang refers to the sun, month, nature and form to lay open contents of intention consisting in in sentence. expansion from word has presentation of word a fuguryang relates to applies synonymy term, sound spelling, the and action, intention of similar meaning, and equation of certain things, and so. charge filled from sengkalan to show image of situation of time and certain place, and express case of event of at one time and certain place also.
\end{abstract}

Keywords: candrasengkala, suryasengkala, picture, ornament, figure

\begin{abstract}
ABSTRAK
sengkalan merupakan ekspresi wujud dari ungkapan masyarakat jawa, sengkalan lamba memiliki tiga unsur yaitu diantara kalimat atau kata, figur, dan tahun. sengkalan memet adalah suatu penanda yang divisualisasikan dalam bentuk gambar, pusaka, patung, perhiasan, kereta yang mewakili dari suatu ekspresi penyampaian maksud tertentu. penyajian sengkalan dalam susunan kata berdasarkan arti dan karakteristikyang mengacu pada matahari, bulan, sifat dan wujud untuk mengungkapkan isi maksud yang terkandung di dalam kalimat. pengembangan dari kata mempunyai penyajian kata suatu fuguryang berkaitan dengan menggunakan istilah kesinoniman, ejaan bunyi, hal dan tindakan, maksud arti yang serupa, serta persamaan hal-hal yang tertentu, dan seterusnya. muatan isi dari sengkalan menunjukkan gambaran situasi waktu dan tempat tertentu, serta menyatakan kejadian peristiwa pada suatu waktu dan tempat yang tertentu juga.
\end{abstract}

Kata Kunci: candrasengkala, suryasengkala, gambar, perhiasan, figur

* Febrian Wisnu Adi (sepskd@yahoo.com), Tenaga Pengajar Jurusan Kriya Fakultas Seni Rupa Institut Seni Indonesia Yogyakarta. 


\section{PENDAHULUAN}

Orang Jawa banyak yang suka membuat sengkalan, kalimat dan katakatanya berwatak bilangan, sehingga tersusun angka tahun seperti yang dituliskan pada pintu gerbang halaman rumah atau kuburan. Demikian pula bukubuku bacaan Jawa hampir semua mencantumkan saat penulisanya dengan sengkalan mengingat sesuatu bisa dilakukan dengan berbagai cara. Apalagi yang berkaitan dengan angka-angka petunjuk waktu, meletusnya gunung berapi, bertahtanya dan wafatnya seorang raja, berdirinya atau runtuhnya suatu keraton, dan segala hal yang dianggap penting lainya. Menggunakan nama-nama binatang, tumbuhan ataupun alam semesta, merupakan simbol-simbol yang digunakan untuk menggantikan bilangan waktu.

Orang Jawa jaman dahulu, terbiasa menggunakan cara ini sebagai penanda tahun suatu peristiwa. Suatu susunan rangkaian kalimat indah yang terdiri dari empat kata, membentuk sebuah makna tertentu, begitulah yang disebut sebagai sengkalan. Sebagian besar sengkalan merupakan sengkalan Candrasengkala. Candra berarti bulan, maksudnya Sengkalan yang penulisan angka tahunnya berdasarkan peredaran bulan mengelilingi bumi (lunar calendar). Sengkalan Candrasengkala digunakan setelah masa Islam dengan memakai tahun Jawa. Tahun Jawa ditetapkan oleh Sultan Agung Hanyakrakusuma sejak 1 Suro 1555 Jawa, bertepatan 1 Muharam 1043 Hijriah, atau 1 Srawana 1555 Saka, atau 8 Juli 1633 Masehi. Tahun Jawa merupakan perpaduan antara tahun Hijriah dengan tahun Saka. Sedangkan sengkalan yang angka tahunnya berdasarkan peredaran bumi mengitari matahari (Solar Calendar) disebut Surya Sengkala, misalnya tahun Masehi. Surya berarti matahari. (Waluyo Wijayanto, 2007:30)

Candrasengkala merupakan catatan untuk memperingati atau perhitungan-perhitungan tahun dengan kalimat atau susunan kata-kata, bukan dengan angka. Keperluan yang diperingati dengan susunan kalimat, supaya mudah dalam mengingat-ingatnya dan tak dapat berubah sebab kalau berubah sedikit saja, makna juga sudah beda dan terasa janggal. Belum ada catatan resmi yang menyebutkan sejak kapan sengkalan ini mulai dipergunakan, namun dari beberapa kitab lama seperti Pararaton, Nagara Kertagama, atau Babad Tanah Jawi, candrasengkala telah digunakan. Pastinya sengkalan lazim digunakan para pujangga dan bangsawan keraton untuk menandai suatu peristiwa tertentu. Dalam sejumlah catatan seperti Pararaton, yang ditulis pada jaman Prabu Hayam Wuruk yang memerintah kerajaan Majapahit pada tahun 1350 hingga 1389 Masehi, agaknya sengkalan sudah digunakan. Daerah Sadeng, yang diperkirakan sekarang Besuki, yang telah ditundukan Majapahit, pada tahun 1253 tahun saka atau 1331 Masehi yang tercermin dalam candrasengkala: Kaya Bhuta Non Danging, Kaya (3); Bhuta (5); Non (2); Danging (1) yang berarti seperti raksasa melihat daging.

Sengkalan menyimpan makna angka yang harus diterjemahkan terbalik. Kata pertama dan kedua dalam kalimat 
sengkalan, merupakan angka satuan dan puluhan dari tahun terjadinya peristiwa. Sedangkan kata ketiga dan paling akhir dari kalimat sengkalan, justru menandai abad ketika peristiwa itu terjadi. Sirna llang Kertaning Bumi "hilang lenyap ketentraman dunia" adalah angka tahun 1400 Saka, atau Tahun 1478 Masehi, yang merupakan sengkalan keruntuhan kerajaan Majapahit. (R. Bratakesawa, 1980:21)

Suatu peristiwa terjadi memang mudah diingat: kapan terjadinya hanya dengan mengucap kalimat yang indah yang terdiri dari 4 kata. Padahal makna dari sengkalan terkadang juga diberi muatan falsafah tinggi dan sangat rumit dalam pengartianya, atau pesan-pesan moral yang sengaja dimuatkan dan disimpan dalam rangkaian kata tersebut. Semisal, Luhuring Sembah Trusing Allah "Luhur (0); Sembah (2); Trus (9); Allah (1). Berarti angka tahun 1920. Meskipun sengkalan ini menandai yang paling utama adalah yang tertuju kepada Tuhan yang Maha Esa.

Namun mengapa sengkalan harus dibaca dengan teknik terbalik? Ada sejumlah pihak yang menafsirkan, bahwasannya suatu peristiwa, namun kalimat sengkalan sendiri berarti sembah orang Jawa pada dasarnya tidak suka berterus-terang. Semua maksud harus disampaikan secara halus dan penuh dengan filosofi, bahkan kalau perlu hanya tersirat saja. Namun ada pihak lain yang menilai, paham bacaan sengkalan dari kanan kekiri, bisa jadi karena pengaruh agama islam, dimana kalimat-kalimat dalam Kitab Suci dibaca dari kanan ke kiri seperti halnya dalam bahasa Arab. (Waluyo Wijayanto, 2007:31)
Hal yang sangat menarik, orangorang Jawa masa lalu memakai obyekobyek alam yang bersifat kekal dalam wujud atau sifatnya. Sengkalan Angka Nol (0). Angka nol dalam sengkalan disimbolkan dengan kata-kata yang berarti hilang atau segala sesuatu yang tidak ada. Pada sengkalan hanya ada satu kata yang bernilai nol atau kosong, yaitu kata umbul (melesat ke atas) karena segala sesuatu yang telah hilang bernilai nol. Misalnya sengkalan tentang pelaksanaan sekaten tahun 1990, "umbuling puspa gapuranin praja".

Sengkalan Angka Satu (1). Angka satu di dalam sengkalan disimbolkan dengan kata-kata yang bermakna satu, kata-kata yang bermakna jumlahnya hanya satu, benda yang bentuknya bulat, katakata yang berarti manusia, kata-kata yang berarti hidup dan nyata. Kata-kata pada sengkalan yang bernilai satu adalah jalma, jalmi, janma, kenya, putra, aji, ratu, raja, nata, narpati, narendra, pangeran, gusti, Allah, hyang, maha, bathara, bumi, jagat, budi, buda, budaya, ron, lata, wani, semedi, luwih, nabi, lajer, wiji, witana, praja, bangsa, swarga, puji, piji, harja dan peksi. Kata peksi bernilai satu, namun sebenarnya bernilai dua, karena peksi berasal dari kata peksi (sansekerta) yang berarti burung atau binatang yang bersayap.

Sengkalan Angka Dua (2). Angka dua di dalam sengkalan disimbolkan dengan kata-kata yang mempunyai makna berjumlah dua, atau berpasangan dan bentuk-bentuk turunannya, serta kata-kata yang bermanka gandheng. Kata-kata pada sengkalan yang bernilai dua, biasanya 
digunakan kata asta, dwi, kembar, ngelmi, aksa, samya, embah dan supit.

Sengkalan Angka Tiga (3). Angka tiga dalam sengkalan disimbolkan dengan kata-kata yang mempunyai makna berjumlah tiga, dan bentuk-bentuk turunannya. Kata-kata pada sengkalan yang bernilai tiga, biasanya digunakan kata guna, katon, saut, sunar, trima, trisula, ujwala, dan wredu.

Sengkalan Angka Empat (4). Angka empat dalam sengkalan disimbolkan dengan kata-kata yang berarti air dan katakata yang berarti kerja, serta segala sesuatu yang berjumlah empat. Kata-kata pada sengkalan yang bernilai empat ialah kata papat, catur, keblat (arah mata angin), warna (kasta dalam agama Hindu), toya (air), suci dan pakarti.

Sengkalan Angka Lima (5). Angka lima dalam sengkalan disimbolkan dengan kata-kata yang mempunyai makna berjumlah lima, golongan raksasa, segala macam senjata, kata-kata yang berarti angin, tajam, ilham atau bisikan, perangkap, serta kata-kata yang mempergunakan kata panca. Kata-kata pada sengkalan yang bernilai lima ialah driya (indra), wisaya (cerapan indra), cakra, warayang,t inulup, ati, linungit, yaksa, mangkara, marganing, pasarean, tinata, gati dan pirantining.

Sengkalan Angka Enam (6). Angka enam dalam sengkalan disimbolkan dengan kata-kata yang berarti rasa, hewan berkaki enam, dan segala sesuatu yang bergerak. Kata-kata pada sengkalan yang bernilai enam ialah kat gana, hanggahangga, (laba-laba), rasa, sinesep, nikmat, kayu, winayang (digerakkan), rebah (runtuh) dan wisik (pesan).
Sengkalan Angka Tujuh (7). Angka tujuh dalam sengkalan disimbolkan dengan kata-kata yang mempunyai arti golongan pertapa atau pendeta, gunung, suara, serta binatang yang biasa dipergunakan untuk kendaraan. Kata-kata pada sengkalan yang bernilai tujuh ialah kata pandhita, resi, swara, sabda, muji (pujian, restu, ajar) dan giri, gunung).

Sengkalan Angka Delapan (8).
Angka delapan dalam sengkalan
disimbolkan dengan kata-kata yang berarti gajah, binatang melata, dan brahmana. Kata-kata pada sengkalan yang bernilai delapan adalah kata ngesti (memikirkan), madya (tengah), basuki, naga, brahmana, manggala, murti, salira, sarining, dan katakata turunandarikata-katatersebut.

Sengkalan Angka Sembilan (9). Angka sembilan dalam sengkalan disimbolkan dengan kata-kata yang mempunyai arti dewa, bunga dan bendabenda yang berlubang atau terbuka. Katakata pada sengkalan yang biasanya digunakan untuk menyatakan angka sembilan ialah : kata, trus, trustaning, wiwara, anggatra, gapura, ambuka, makaring, umanjing, sekaring, puspa, kusuma, kembang, dan ngarumake (mengharumkan).

Menurut bentuknya Sengkalan sendiri dibedakan menjadi beberapa sengkalan antara lain:

1. Sengkalan Lamba. Sengkalan yang menggunakan rangkaian kata.

2.Sengkalan Memet. Sengkalan yang berwujud rupa.

3. Sengkalan Sastra. Sengkalan yang menggunakan huruf Jawa dan sandangannya biasa digunakan pada ukir-ukiran, hiasan keris, dan lain 
sebagainya.

(www.bravo172.blogspot.com)

Sengkalan yang tidak berupa kalimat tetapi berwujud rupa atau gambar obyek-obyek tertentu dalam bentuk gambar, lukisan arca, wayang, gambar hewan, dan gambar tumbuh-tumbuhan yang melambangkan angka-angka tahun yang dimaksud dan sangat rumit untuk mengartikannya, sengkalan semacam ini disebut sengkalan memet. Memet artinya rumit. Memang cukup rumit untuk menafsirkan angka dari sebuah rupa atau gambar. Sebagai contoh: seperti sengkalan memet yang berada di Kerataon Surakarta pada Pangung Sangga Buana (Pentas Penyangga Dunia) dengan susunan katakata yang bunyinya: Naga Muluk Tinitian Janma (Naga Terbang Dikendarai Orang) naga menunjukan angka 8; muluk (terbang) menunjukan angka 0; tinitian (dikendarai) menunjukan angka 7; janma (orang) menunjukan angka 1. Cara dalam membaca sengkalan dengan metode dibalik, angka yang paling belakang dibalik menjadi didepan jadi dibaca tahun 1708. Tetapi pernyataan kata-katanya tidak menggunakan tulisan berupa kalimat tetapi bentuk karya senirupa bisa berupa lukisan, arca, wayang, gambar dua dimensi, maupun monumental.

Contoh lain adalah di bangsal Kemagangan Keraton Kasultanan Ngayogyakarta Hadiningrat (Kerajaan Yogyakarta) terdapat sengkalan memet berupa gambar dua naga yang menjulur yang menjulur horizontal, bertolak belakang, masing-masing menghadap kekiri dan kekanan. Sedangkan ekor kedua naga saling berlilitan menjadi satu ditengah. Bila ditafsirkan dalam kalimat bahasa jawa: Dwi Nogo Roso Tunggal (Dua Naga Menyatu Rasa) yang melambangkan angka tahun 1682 Jawa (Dwi menunjukang angka 2, Naga menunjukan angka 8, Rasa menunjukan angka 6 , Tunggal menunjukan angka 1. Atau dalam hitungan kalender Masehi, adalah tahun 1760. Tahun ini adalah tahun mulai dibangunya Keraton Yogyakarta. Pendapat lain mengatakan bahwa sengkalan memet tersebut berbunyi: Dwi Nogo Roso Tunggal (Dua Negara Yang bersatu). Kedua tafsir kalimat sengkalan tersebut sebenarnya memiliki maksud yang hampir sama. Yakni semboyan tentang adanya dua negara (dilambangkan oleh wujud naga) yang menyatu sikap (berkolaborasi) menentang kolonialis Belanda pada jaman itu. Akan tetapi sikap perlawanan ini tidak ditunjukan secara terbuka, tetapi merupakan politik dibelakang layar. Hal ini dilambangkan pada bagian belakang naga (ekor) yang saling berlilitan, sedang kepala naga masing-masing menghadap keluar (kiri dan kanan) sebagai lambang sikap politik diplomasi ramah-tamah terhadap penjajah Belanda.

Dengan demikian, sengkalan memet lebih sukar diartikan atau menafsirkanya kata atau gambar manakah yang harus dibaca dahulu. Pembaca hanya dengan perkiraan saja, secara untunguntungan, didukung dengan keterangan dan petunjuk. Sebab tidak diketahui siapa pembuatnya dan pada jaman apa atau tahun berapa peristiwa itu terjadi. Oleh karena itu angka-angka di belakang (satuan, puluhan) disebutkan lebih dulu sebagai kata-kata diawal kalimat sengkalan, supaya angka detail yang mudah dilupakan orang ini dapat teringat 
lebih dahulu. Adapun angka-angka ratusan maupun ribuanya rasanya masih lebih mudah diingat atau diperkirakan, maka ditaruh diakhir kalimat. Orang-orang yang pandai menafsirkan sengkalan adalah para budayawan dan pujangga masa lalu. Para sejarawan juga banyak mempelajarinya karena sangat berguna dalam bidang keilmuanya. Dengan kata lain sengkalan merupakan salah satu piranti untuk menelusuri sejarah. (R. Bratakesawa, 1980:107)

Beberapa pedoman tata cara dalam penyusunan sengkalan antara lain:

1. Gurudasanama. Ketentuan dalam penggunaan kata-kata pada sengkalan dengan cara menggunakan sinonim atau dasar padanan kata.

2. Gurusastra. Cara menentukan perubahan atau penurunan kata yang digunakan pada sengkalan dengan memakai homograf atau dasar penulisan yang sama.

3. Guruwanda. Cara menentukan perubahan atau penurunan kata yang digunakan pada sengkalan dengan memakai dasar sesuku kata.

4. Guruwarga. Cara menentukan perubahan atau penurunan kata yang digunakan pada sengkalan dengan memakai dasar sekaum.

5. Gurukarya. Cara menentukan perubahan atau penurunan kata yang digunakan dengan memakai dasar sekerja.

6. Gurusarana. Cara menentukan perubahan atau penurunan kata yang digunakan pada sengkalan dengan memakai dasar sealat.

7. Gurudarwa. Cara menentukan perubahan atau penurunan kata yang digunakan pada sengkalan dengan memakai dasar sekeadaan atau dalam satu keadaan yang sama.

8. Gurujarwa. Cara menentukan perubahan atau penurunan kata yang digunakan pada sengkalan dengan memakai dasar searti atau arti yang sama. ( Rachmat Djoko Pradopo, 1982) Perlambangan sengkalan dapat dianalisis menggunakan tiga hubungan penalaran simbolisme dengan jenis penandanya sesuai dengan teori semiotika Peirce. Ketiga hubungan penalaran tersebut adalah qualisign, sinsign, dan legisign. Qualisign merupakan tanda-tanda yang dapat dibaca berdasarkan sifat benda tersebut. Sifat-sifat tersebut antara lain bentuk dan warna. Agar benar-benar berfungsi sebagai tanda, maka qualisign harus memiliki bentuk. Sinsign merupakan tanda yang didasarkan atas tampilannya dalam kenyataan. Semua pernyataan individual yang tidak dilembagakan dapat disebut sebagai sinsign. Legisign merupakan tanda yang dilembagakan atas dasar suatu peraturan. Sesungguhnya legisign sebuah impilaksi dari sinsign. Tanda yang awalnya bersifat konvensional, karena sudah terbiasa digunakan dan dikenal akhirnya dilembagakan melalui suatu peraturan. Perlambangan angka tahun dalam sengkalan menggunakan aspek simbolisme dalam penanggalan Jawa yang telah dilembagakan secara konvensional dan diterima masyarakat pendukungnya.

Pada aspek etstetisnya, sengkalan memiliki sifat indah dan sublime yang sangat subyektif. Edmund Burke menulis buku yang berjudul "A Philosophical Enquiry Into The Origin Ideas of The 
Sublime and Beautiful" (1767) tentang rasa keindahan. Burke menunjukan 2 respon estetik atas seni :

A. Pengalaman akan yang indah (Pleasure)

B. Pengalaman akan yang sublim (Delight) Keindahan menurut Edmund Burke.

Hakekat keindahan. Keindahan yang dibedakan dari sublim, yang dimaksudkan kualitas dalam tubuh yang bisa menimbulkan rasa cinta atau yang menyerupainya (Simpati). Love dibedakan dengan Desire yang mendorong orang menjadi Possession.

Sumber keindahan

1. Proporsi : diragukan karena bukan hanya kuantitas, belum tentu sebagai syarat bentuk keindahan.

2. Kegunaan : sesuatu harus mempunyai nilai guna.

3. Kesempurnaan : perfection yang menyebabkan keindahan.

4. "Kecil". Beautiful object are small. Dalam beberapa bahasa, object cinta diungkapkan dalam "diminutive epithets" : besar dikecilkan. Misalnya Hussein menjadi Hasan.

5. Halus : Smoothness, karya seni yang tidak halus berarti tidak indah.

6. Imut-imut (delicacy) : gampang rusak, gampang pecah, tidak kokoh.

Sublim muncul untuk menjelaskan "pengalaman" keindahan yang ternyata di dalamnya tidak hanya pleasure, tetapi juga emosi, stress, bahkan rasa tidak enak.

Sublim menurut Burke mempunyai beberapa pengertian :

a. Passion yang disebabkan oleh atau dapat menimbulkan "astonishment" (gerakan batin yang tidak bisa los atau lepas) dalam suasana horor (ketakutan).

b. Pengalaman Sublim terjadi ketika seluruh pikiran kita dipenuhi oleh obyek yang kita hadapi. Astonishment adalah efek dari sublim yang mempunyai efek admiration, reverence dan respect.

c. Sublim dimasukkan dalam bahaya (danger), juga dimasukkan dalam ide kekuatan (power), strength, violence, pain dan teror adalah beberapa ide yang digunakan dalam pikiran.

Istilah lain sublim menurut Burke adalah Delightful Horor.

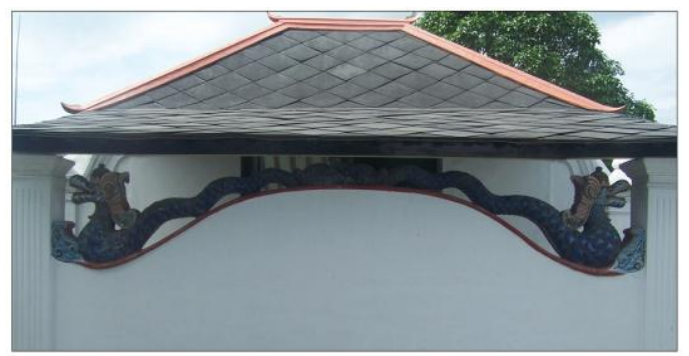

Gambar 1. Gambar sengkalan memet di Bangsal Kemagangan Keraton Kesultanan Ngayoyakarta Hadiningrat. Bila ditafsirkan dalam kalimat berbunyi Dwi Naga Rasa Tunggal (Dua Naga Menyatu Rasa), mengambarkan dua naga yang menjulur horizontal, bertolak belakang, masing-masing menghadap kekiri dan kekanan. Sedang ekornya saling berlilitan ditengah, yang melambangkan angka tahun 1682 Jawa (Dwi menunjukan angka 2; Naga menunukan angka 8; Rasa menunjukan angka 6; Tunggal menunjukan angka 1). Atau dalam hitungan Masehi, adalah tahun 1760. Tahun ini adalah prasasti atau penanda dimulainya pembangunan Keraton Yogyakarta.

(Foto: Febrian , 2012) 


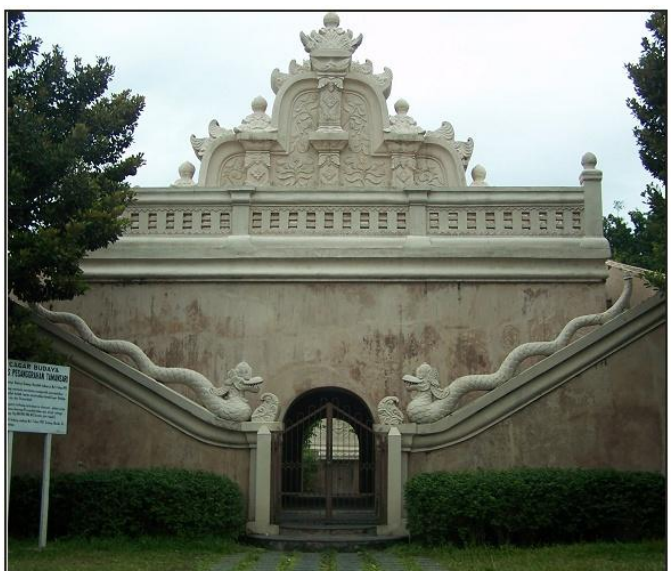

Gambar 2. Gambar sengkalan memet di Taman Sari Keraton Kesultanan Ngayoyakarta Hadiningrat. Bila ditafsirkan dalam kalimat berbunyi Catur Nogo Roso Tunggal (Sepasang Naga Berbicara Menyatukan Rasa). yang melambangkan angka tahun 1684 Jawa (catur (berbicara) menunjukan angka 4; Naga menunjukan angka 8; rasa menunjukan angka 6; Tunggal menunjukan angka 1). Atau dalam hitungan Masehi, adalah tahun 1762. Tahun ini adalah (tetenger) atau prasati penanda sejarah mulainya pembangunan Pesanggrahan Taman Sari yang dibangun setelah Perjanjian Giyanti (1755), yakni setelah Sultan Hamengku Buwana sekian lama terlibat dalam persengketaan dan peperangan. Bangunan tersebut dimaksudkan sebagai bangunan yang dapat dipergunakan untuk meneteramkan hati, istirahat, dan berekreasi. (Foto: Febrian, 2012)

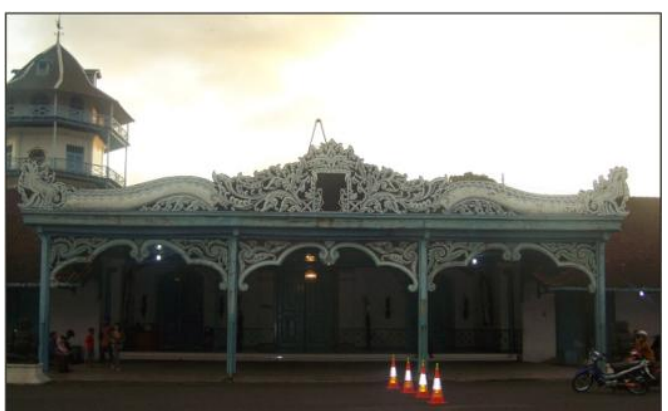

Gambar 3. Gambar sengkalan memet di Pajangan Bale Rata Keraton Kasunanan Surakarta. Bila ditafsirkan dalam kalimat berbunyi: Siung Buta Naga Raja (Dua Naga Raja yang ditengahnya ada Raksasa). Mengambarkan dua naga yang menjulur horizontal, bertolak belakang, masing-masing menghadap kekiri dan kekanan. Sedang ditengah ada gambar raksasa. yang melambangkan angka tahun 1855 Jawa (Siung (taring) menunjukan angka 5; Buta (raksasa) menunjukan angka 5; Naga menunjukan angka 8; Raja menunjukan angka 1). Atau dalam hitungan Masehi, adalah tahun 1933. Tahun ini adalah (tetenger) prasati penanda sejarah perkawinanya antara dua kerajaan Surakarta dan Yogyakarta yaitu Sri Susuhunan Paku Buwana X dengan Gusti Kanjeng Ratu Hemas Putri Sri Sultan Hamengku Buwana VII. (Foto: Febrian , 2012)

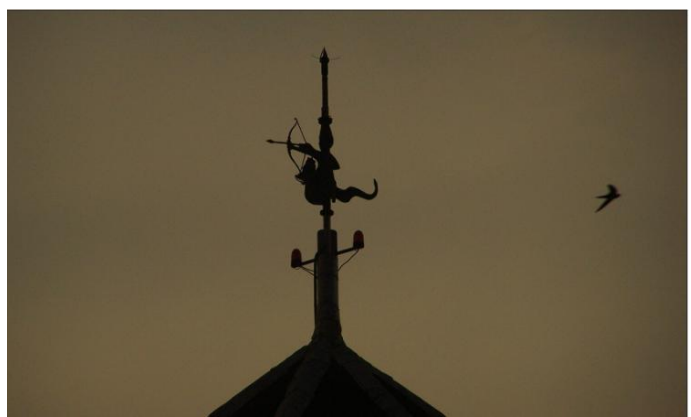

Gambar 4. Gambar sengkalan memet di Panggung Sangga Buwana Keraton Kasunanan Surakarta. Bila ditafsirkan dalam kalimat berbunyi Naga Muluk Tinitian Janma (ular naga sedang terbang dikendarai orang). Mengambarkan ular naga yang sedang terbang, dikendarai manusia yang membawa panah. yang melambangkan angka tahun 1708 Jawa (Naga menunjukan angka 8; Muluk (terbang) menunjukan angka 0; Titihan (tunggangan) menunjukan angka 7; Janma (manusia ) menunjukan angka 1). Tahun ini adalah (tetenger) prasati penanda sejarah pembuatan Panggung Sangga Buana.

(Foto: Febrian , 2012)

\section{KEPUSTAKAAN}

Bratakesawa,

$\mathrm{R}$.

'Ketranagan

Candrasengkala

Jakarta:

Departemen Pendidikan dan Kebudayaan

Proyek

PenerbitanBuku Sastra, 1980.

Feldman, Edmund Burke. Art As Image And Idea. Englewood Cliffs, New Jersey: Prentice-Hall, Inc., 1967.

Haryono, Timbul. Seni Pertunjukan dan Seni Rupa dalam Perspektif Arkeologi Seni. Solo: ISI Press Solo 2008.

Hauser, Arnold. The Sociology Of Art, Terj. Kenneth J. Chicago dan London: 
The University of Chicago Press, 1974.

Majalah Keris,edisi 4, 2007, Waluyo

Wjayanto: Sengkalan.

Margono, S. Kraton Surakarta dan Yogyakarta 1769-1874. Yogyakarta: Pustaka Pelajar, 2004.

Moedjanto, G. Konsep Kekuasaan Jawa: Penerapannya Oleh Raja-Raja Mataram. Yogyakarta: Kanisius, 1987.

Pradopo, Djoko Rachmat, Widya Parwa.

Kritik Sastra, Guna, dan Faedahnya, Yogyakarta: Balai Penelitian Bahasa Departemen Pendidikan dan Kebudayaan, 1982.

Sedyawati, Edi. Budaya Indonesia: Kajian Arkeologi, Seni, dan Sejarah. Jakarta: PT. Raja Grafindo Persada, 2007.

Soekiman, Djoko. Kebudayaan Indis Dan Gaya Hidup Masyarakat Pendukungnya Di Jawa (ABAD XVIII-MEDIO ABAD XX), Yogyakarta: Yayasan Bentang Budaya, 2000.

Sunardi, St. "Sosiologi Genetik PolitikBudaya Piere Bourdieu".

\section{Intrrnet}

www.bravo172.blogspot.com 